\title{
VIŠEKRITERIJUMSKA OCENA INTERNET PREZENTACIJE BEOGRADA ZA STRANE TURISTE
}

\author{
Mališa R. Žižović ${ }^{1}$, Verka Jovanović ${ }^{1}$, Miodrag M. Žižović ${ }^{2}$, Nada Damljanović ${ }^{2}$ \\ ${ }^{1}$ Univerzitet Singidunum, Srbija \\ ${ }^{2}$ Tehnički fakultet u Čačku, Srbija
}

\begin{abstract}
:
U ovom radu su razmatrane internet prezentacije grada Beograda koje su namenjene stranim turistima. Dat je prikaz nekih celina i njihovih sajtova. Posebna pažnja usmerena je na muzeje u Beogradu, pa je za muzeje ovde i dato uputstvo za prezentovanje Beograda i naše zemlje. Dalje, izvršena je višekriterijumska analiza internet prezentacija turističke ponude Beograda sa dva glavna stanovišta- sa stanovišta interesovanja turiste i sa druge strane sa stanovišta organizatora prezentacije.
\end{abstract}

\author{
Key words: \\ prezentacija, \\ websajt, \\ strani turista, \\ muzej, \\ višekriterijumska analiza.
}

\section{UVOD}

Ako se posmatra poseta turista turističkim destinacijama u Srbiji, uključujući pri tom i ljude koji dolaze poslovno, Beograd je najatraktivnija turistička destinacija.

Tabela 1. daje prikaz broja poseta turista od 2009. do 2013. godine u Beogradu.

Tabela 1. Turisti u Beogradu

\begin{tabular}{|c|c|c|c|}
\hline \multicolumn{5}{|c|}{ Posetioci } \\
\hline Godina & Domaći & Strani & Ukupno \\
\hline 2009 & 125076 & 343776 & 468852 \\
\hline 2010 & 124681 & 378194 & 502875 \\
\hline 2011 & 119218 & 420004 & 539222 \\
\hline 2012 & 116249 & 450685 & 566934 \\
\hline 2013 & 120778 & 517401 & 638179 \\
\hline \multicolumn{4}{|c|}{ Noćenja } \\
\hline Godina & Domaći & Strani & Ukupno \\
\hline 2009 & 432731 & 802929 & 1235660 \\
\hline 2010 & 411442 & 792608 & 1204050 \\
\hline 2011 & 406668 & 850629 & 1257297 \\
\hline 2012 & 420405 & 917239 & 1337644 \\
\hline 2013 & 392298 & 1016739 & 1409037 \\
\hline
\end{tabular}

Izvor: Zavod za informatiku i statistiku, Beograd, 2014
Iz date tabele se lako vidi da svaki strani turista ima prosečno oko dva noćenja u Beogradu. Dakle, njegovo vreme boravka u Beogradu nije veliko i ako pretpostavimo da ima višestruka interesovanja, onda on nema mnogo vremena za zadovoljenje svih potreba.

Ovde će biti napravljena analiza internet prezentacija turističke ponude Beograda sa dva glavna stanovišta- sa stanovišta interesovanja turiste (kroz odgovarajuću povećanu preferenciju za određenu vrstu turističke ponude) i sa druge strane sa stanovišta organizatora prezentacije, kroz hipotetičko rangiranje prema uspešnosti prikaza Beograda i naše zemlje.

\section{KRATAK PRIKAZ POJEDINIH CELINA I NJIHOVIH SAJTOVA}

\section{Muzeji u Beogradu}

Muzeji u Beogradu, kao deo šire kulturne baštine gotovo da su izgubili značaj u savremenoj turističkoj ponudi grada. Najveći (glavni) muzej u Srbiji i Beogradu je Narodni muzej koji u zadnjih desetak godina uglavnom ne prima posetioce.

Muzej savremene umetnosti se takođe nalaze u stanju rekonstrukcije. Postoji nekoliko manjih muzeja koji uspešno rade, ali je pitanje koliko je interesovanje i broj posetilaca tih muzeja. Najčešće, za te specijalizovane muzeje se interesuje uži krug ljudi. Od muzeja koji su zanimljivi i strancima, ističe se Muzej Nikole Tesle i muzejsko-memo- 
rijalni prostor Kuća cveća. Muzej nauke i tehnike koji se nalazi u Skender Begovoj ulici u prostoru bivše termoelektrane (koja je kao zgrada te namene i sama muzejski prostor) ima mali deo iskorišćenosti. Bilo bi korisno da se u ovom prostoru objedini prezentacija muzeja i muzejskog rada u Beogradu uz predstavljanje izuzetno vrednog materijalnog i kulturnog nasleđa grada i znamenitih stvaralaca.

Napomenućemo neke od važnijih činjenica koje bi tu mogle da budu prezentovane (nalazile bi se i na odgovarajućem sajtu koji bi bio pozivnica da se to ovde i vidi):

- Lazar Hilandarac i njegov časovnik (u Kremlju);

- Rekonstrukcija Tesline laboratorije iz Kolorada;

- Pupinova otkrića, knjige i dr. , njegova uloga u stvaranju Jugoslavije 1918. i 1919. godine;

- Računar za rešavanje diferencijalnih jednačina, rad Mihaila Petrovića-zlatna medalja na svetskoj izložbi 1900. godine u Parizu. Potom nagrada Londonskog matematičkog društva (postoji i napravljen prototip koji je bio izložen u Parizu);

- Biografije i zasluge 100 najznačajnijih Srba (akademija SANU);

- Stvaranje Srpske države-srednji vek;

- Obnavljanje Srpske države- XIX vek, uloga kneza Miloša u tome, uloga Karađorđevića u tome;

- Sretenjski ustav iz 1835. godine;

- Ukidanje feudalizma u Srbiji;

- Izjednačavanje svih veroispovesti po tom ustavu;

- Kulturna dobra - Nobelova nagrada Ivi Andriću;

- Sportski uspesi-vaterpolisti-reprezentacija, Partizan, Zvezda, košarkaši- reprezentacija, Partizan, teniseri- N. Đoković, A. Ivanović, J. Janković, reprezentacija, fudbaleri - Crvena Zvezda, odbojkaši i dr.

Mnoge druge činjenice koje nisu navedene mogu da budu deo savremene, sveobuhvatne prezentacije grada Beograda u jedinstvenom prostoru na Dorćolu, tom autentičnom delu grada.

Sa ovakvim pristupom, koji može biti lako ostvaren i svakodnevnim radom muzeja, predstavljanje grada i njegove ponude bi bilo veoma dobro ocenjeno, bez obzira što "glavni" muzeji praktično ne rade.

\section{Sakralni objekti}

Sakralni objekti Beograda su relativno dobro prikazani na nekim sajtovima u Beogradu, mada bi strožiji kritičari imali nekih zamerki.

\section{Galerije}

Galerije i uopšte kulturna dešavanja su uglavnom dobro prikazani.

\section{Arhitektura}

Arhitektura Beograda nije prikazana u najboljem svetlu. Mada je arhitektura nosilac identita grada i njegovih stanovnika i događaja kroz istoriju (Beograd često rušen i uništavan) njeno predstavljanje nije ni dovoljno ni dobro osmišljeno.

\section{Restorani}

Restorani, klubovi i splavovi su relativno dobro prikazani (mada pojedini samo na srpskom jeziku).

\section{Gradski saobraćaj}

Gradski saobraćaj ima relativno dobar sajt, mada nije pogodan za one koji ne znaju kako da se u Beogradu stigne od tačke A do tačke B.

\section{Atrakcije}

Pojedine gradske celine (Kalemegdan, dvorovi, Skadarlija i dr.) su prikazani uglavnom dobro kao atrakcije, mada mogu da čine celinu D.- arhitektura.

\section{VIŠEKRITERIJUMSKA ANALIZA WEB PREZENTACIJA BEOGRADA}

U radu će biti izvršena višekriterijumska analiza internet prezentacija turističke ponude Beograda.

Metode višekriterijumške analize se svakodnevno koriste pri donošenju odluka veće ili manje važnosti. Problem višekriterijumskog odlučivanja se svodi na zadatak poređenja alternativa ocenjenih prema većem broju različitih kriterijuma (najčešće različitog relevantnog značaja) primenom odgovarajućeg računa. Za dati skup alternativa i dati skup kriterijuma, prirodno se nameće pitanje koja alternativa je najbolja?

Tokom poslednjih decenija razvijen je veliki broj metoda i tehnika višekriterijumskog odlučivanja. Za pregled dostupnih metoda upućijemo na monografiju M. Radojičić, M. Žižović (1998). Potraga za optimalnim rešenjem dovela je do velikog broja različitih tehnika i metoda u okviru naučnih disciplina kao što su operaciona istraživanja, menadžment, računarske nauke, statistika i dr. U kombinaciji sa upotrebom modernih računara, mnoge od ovih metoda imaju dobro razvijenu softversku podršku. Metode višekriterijumskog odlučivanja mogu se primeniti u raznim konkretnim situacijama, na primer neke od metodologija mogu se videti u radovima M. M. Žižović i dr. (2010-2013), i M. Žižović (2013).

U ovom radu izvršićemo višekriterijumsku analizu web prezentacija Beograda. Za ocenjivanje i rangiranje alternativnih izbora koristićemo Mrežni metod koji je uveo M. Žižović i dr. (2011).

$\mathrm{U}$ Tabeli 2. navedene su alternative koje ćemo razmatrati u ovom primeru. Naime, imajući u vidu da prosečan turista u Beogradu ne boravi dugo (u proseku dva noćenja) i da nema mnogo vremena za zadovoljenje svih potreba, odnosno obilazak svih turističkih ponuda grada Beograda, ovde ćemo razmotriti neke najčešće alternativne izbore. Napomenimo da se sledeća višekriterijumska metodologija može primeniti na analogan način i ako uzmemo u obzir veći polazni skup alternativa.

Tabela 2

\begin{tabular}{|c|c|}
\hline \multicolumn{2}{|c|}{ Alternative } \\
\hline$A_{1}$ & Muzeji, arhitektura, zabava, restorani, šoping. \\
\hline$A_{2}$ & Galerije, sakralni objekti, šoping. \\
\hline$A_{3}$ & Događaji, restorani, šoping. \\
\hline$A_{4}$ & Atrakcije, restorani, muzeji, šoping. \\
\hline
\end{tabular}


Ovaj skup alternativa ocenićemo prema kriterijumima prikazanim u Tabeli 3.

Tabela 3

\begin{tabular}{|l|l|}
\hline \multicolumn{2}{|c|}{ Kriterijumi } \\
\hline$C_{1}$ & $\begin{array}{l}\text { Karakteristike sajtova (brzina otvaranja, } \\
\text { višejezičnost, lako nalaženje informacija,...). }\end{array}$ \\
\hline $\mathrm{C}_{2}$ & Dizajn sajta. \\
\hline $\mathrm{C}_{3}$ & Informativnost sa stanovišta korisnika. \\
\hline $\mathrm{C}_{4}$ & $\begin{array}{l}\text { Informativnost sa stanovišta prikaza naših vred- } \\
\text { nosti. }\end{array}$ \\
\hline
\end{tabular}

Višekriterijumsko rangiranje predloženih alternativa po datim kriterijumima, biće izvršeno na osnovu Mrežnog metoda za višekriterijumsko ocenjivanje. Ovaj metod se bazira na računanju rastojanja date alternative $A_{i}$ od hipotetički idealne- najbolje alternative $A^{*}$ i hipotetički najgore alternative $A_{*}$. U račun se uključuje čitav niz parametara, počev od onih uobičajenih kojma se uzima u obzir značaj važnosti kriterijuma, do onih koji su za ovaj metod specificni kao što su funkcije kojima se opisuje značaj razlike između alternativa. Za jednu alternativu kažemo da je bolja od druge ako je bliža hipotetički najboljoj alternativi $A^{*}$ i udaljenija od hipotetički najgore alternative $A_{*}$.

Ekspertske ocene datih alternativa prema predloženim kriterijumima prikazane su u Tabeli 4 .

Tabela 4

\begin{tabular}{|c|c|c|c|c|}
\hline & $\mathrm{C}_{1}$ & $\mathrm{C}_{2}$ & $\mathrm{C}_{3}$ & $\mathrm{C}_{4}$ \\
\hline $\mathrm{A}_{1}$ & 4 & 5 & 5 & 6 \\
\hline $\mathrm{A}_{2}$ & 6 & 5 & 6 & 5 \\
\hline $\mathrm{A}_{3}$ & 7 & 6 & 6 & 4 \\
\hline $\mathrm{A}_{4}$ & 5 & 4 & 7 & 8 \\
\hline
\end{tabular}

Primenom Mrežnog metoda dobijen je sledeći rang alternativa

$$
A_{4} \rightarrow A_{3} \rightarrow A_{2} \rightarrow A_{1},
$$

čime je istaknuta prednost alternative $A_{4}$ u odnosu na ostale upoređivane.

\section{ZAKLJUČAK}

Svaka turistička organizacija prezentuje svoje turističke destinacije na razne načine. Jedan od najefikasnijih, a pri tom i najjeftinijih načina prezentovanja jeste prezentovanje putem Interneta, odnosno preko web sajtova. Zbog toga se ovi sajtovi moraju dobro i pažljivo pripremiti, oni moraju biti sadržajni, u potpunosti korektni, tačni i informativni, ali isto tako i jasni i laki za korišćenje. Njihova važnost može da se sagleda i sa stanovišta onoga ko putuje $i$ onoga ko se prezentuje. U oba slučaja, Internet prezentacija se ocenjuje na osnovu više različitih kriterijuma.

U ovom radu izvršena je višekriterijumska analiza Internet prezentacija grada Beograda za strane turiste osnosno turističke tražnje. Pored osnovnih karakteristika sajta, neki od bitnih faktora pri ocenjivanju su i višejezičnost sajta, odnosno mogućnost prikazivanja sajta na više različitih jezika, zatim atraktivnost-dizajn sajta, kao i informativnost sajta sa stanovišta korisnika i sa stanovišta prikaza vrednosti grada Beograda.

U radu je dato uputstvo za prezentaciju muzeja, a u prikazima na sajtovima ostalih celina se na sličan način lako može napraviti uputstvo za prezentaciju Beograda i naše zemlje. U tom slučaju bi se i odgovarajuće ocene premenile i generalno bi bile veće.

\section{LITERATURA}

[1] M. Radojičić, M. Žižović, Applications of methods of multi criteria analysis in buissnis decision making, Technical faculty in Čačak, Serbia 1998 (Monograph in Serbian).

[2] M. Žižović, N. Damljanović, V. Lazarević, N. Deretić, New method for multicriteria analysis, U.P.B. Sci. Bull. Series A 73 (2) (2011) 13-22.

[3] M. M. Žižović, V. Jovanović, Proposal evaluation methodology for computer applications in Tourist-hotel facilities, Unitech'10, Gabrovo (2010) III-171-III-174.

[4] M. M. Žižović, V. Jovanović, Evaluation of medical spa resorts, Unitech'11, Gabrovo (2011) III-159-III-162.

[5] M. M. Žižović 2011. Application of computer technology in tourism industry of Moravica district, Master thesis Universety Singidunum, Belgrade, Serbia, 2011.

[6] M. Žižović, N. Damljanović, O. Nikolić, N. Deretić, New MCD-method, UNITECH'13, Gabrovo, Bulgaria, 2013, III109-III-112 (ISSN 1313-230X).

[7] M. M. Žižović, N. Damljanović, D. Turanjanin, M. Žižović, Multicriteria analaysis of use alternative sources of energy from biomass, UNITECH'13, Gabrovo, Bulgaria, 2013, III161-III-164 (ISSN 1313-230X).

\section{MULTI-CRITERIA EVALUATION OF WEBSITE OF BELGRADE FOR FOREIGN TOURISTS}

\footnotetext{
Abstract:

In this paper, we consider the websites of Belgrade intended for foreign tourists. An overview of some units and their websites is given. Special attention is focused to the museums in Belgrade, and for museums here are given instructions how and were to present Belgrade and our country.

Furthermore, here is given a multi-criteria analysis of web sites of tourist offer of Belgrade with two main standpoint-from the standpoint of interest of tourists and on the other hand from the standpoint of the organizers of the presentation.
}

\section{Key words:}

presentation, website, foreign tourists, museum, multi-criteria analysis. 